\title{
Show, tell and re-enact: The reason why the earliest followers of Jesus found the Eucharist meaningful
}

\author{
Author: \\ Jonanda Groenewald ${ }^{1}$ \\ Affiliation: \\ ${ }^{1}$ Department of New \\ Testament Studies, \\ University of Pretoria, \\ South Africa \\ Note: \\ This article is based on \\ a section of Jonanda \\ Groenewald's DD \\ dissertation (2005), \\ entitled 'Baptism, \\ Eucharist, and the earliest \\ Jesus-groups - from the \\ perspective of alternate \\ states of consciousness', \\ with, as supervisor, Prof. \\ Dr Andries G. van Aarde, \\ Faculty of Theology, \\ University of Pretoria, \\ South Africa.
}

\section{Correspondence to:} Jonanda Groenewald

email:

jonandagroenewald@

yahoo.com

Postal address:

8 Manse Court, East Calder

Livingston, EH53 OHF,

Scotland

\section{Dates:}

Received: 30 May 2010

Accepted: 08 July 2010

Published: 07 June 2011

How to cite this article:

Groenewald, J., 2011,

'Show, tell and re-enact:

The reason why the earliest

followers of Jesus found

the Eucharist meaningful',

HTS Teologiese Studies/

Theological Studies 67(1),

Art. \#877, 10 pages. DOI:

10.4102/hts.v67i1.877

(C) 2011. The Authors. Licensee: OpenJournals Publishing. This work is licensed under the Creative Commons Attribution License.
The purpose of this article has been to examine how the earliest followers of Jesus experienced the Eucharist. What was their reason for participating in the Eucharist? What kind of value did this rite add to their lives? What was the meaning attached to it? In the end, this approach might assist us to gain a deeper understanding of this 'early Christian' rite, which, in turn, could help us to comprehend what kind of value the Eucharist could add to our lives today.

\section{Introduction}

\section{Purpose}

The earliest evidence ${ }^{1}$ that we possess indicates that the Eucharist played an important role in the lives of the first followers of Jesus from the very beginning. ${ }^{2}$ In one way or another, many Christians in a Eurocentric world today still participate in this rite, but it is debatable whether Westerners religiously experience this sacrament of the contemporary institutionalised church in a similarly meaningful way, compared to how it was experienced 2000 years ago.

The purpose of this article is to examine how the earliest followers of Jesus experienced the Eucharist. What was their reason for participating in this rite? What kind of value did this rite add to their lives? What was the meaning attached to it? In the end, this approach might assist us to gain a deeper understanding of this 'early Christian' rite, which, in turn, could help us to comprehend what kind of value the Eucharist could add to our lives today.

I am of the opinion that this investigation could be especially fruitful, because institutionalised churches today are entering a phase of deinstitutionalisation ${ }^{3}$ (cf. Dreyer 2004:920, 929-932; Fox 1990:15-18; Van Aarde 1995) and this rite came into being before formative Christianity became an institution. Where some postmodern believers might want to disperse of everything that reminds them of the institutionalised church (cf. Schutte 2004), this article could assist them to realise once again what the value of the Eucharist could be, without the tag of 'formalism' being attached to this rite.

\section{Rites}

In the 1st century Mediterranean world, religion did not function as an isolated phenomenon in culture. The social world and the symbolic universe as a 'sacred canopy' mutually influenced each other (see Berger 1967:3-51). In this holistic, symbolic and social world the Eucharist was a symbolic event which was meaningful for people.

The Eucharist can be described as a rite. The term 'rites' can be understood as a general concept that covers both rituals and ceremonies (Neyrey 1990:76). Rites are closely connected to purity. In the words of Malina (1986:21), purity concerns the socially contrived lines through time and space

1. Here I refer to the documents included in the New Testament and other early apocryphal documents that are related to this theme, as well as the writings of the church fathers.

2.With regard to the way in which I describe the people we read about in the Bible, the reader should note the following: Throughout this article I use the terms 'Israelites' or 'Israelite', instead of 'Jews' or 'Jewish', because the latter is an anachronism. The term 'Judean'

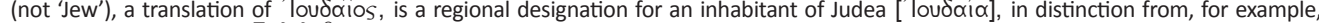
an inhabitant of Galilee [ $\left\lceil\alpha \lambda_{1} \lambda \alpha \hat{i}_{0}\right.$ ] (see Pilch 1997a:119-125). I refer to the temple-centred religion of both Judeans and Galileans as the religion of post-exilic 'Israelites'. 'Insiders', who supported the ideology of the Second Temple, referred to themselves as the 'people of God' or the 'house of Israel' (e.g. Mt 10.6) (see Elliott 1995:76). Geographically perceived, Galilee and Idumea, which were situated concentrically around Judea, were regarded as regions with a lo

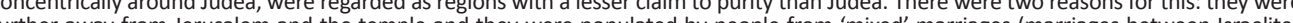
further away from J ( ( Xplotiavol [Christians'] is a similar example of stereotyping used by Judeans and Romans to refer to Jesus-followers in, for example, Syria (see Ac 11:26). Therefore, from an 'in-group' perspective, the term 'Christians' is not a suitable description for the very first followers of Jesus. (I therefore employ inverted commas when I do need to use these terms in this article.)

3.See Yolanda Dreyer's (2004:920, 929-932) analysis of the deinstitutionalisation theory of the sociologist Max Weber and her analysis of the structuration theory of Anthony Giddens and Pierre Bourdieu. 
that human groups maintain in order to create and discover meaning (see Segal 1989:142). Once a group develops a set of lines, there are all sorts of reasons and occasions for focusing on the lines, either to cross them or to maintain and strengthen them. Social behaviours concerned with crossing lines constitute rituals, whilst those concerned with maintaining or strengthening purity lines comprise ceremonies. Crossing the lines between being unbaptised and being baptised is an example of a ritual - an event that focuses on the transition to a new, socially recognised state with a resulting change in role or status for the individual concerned. The Eucharist, on the other hand, is an example of a ceremony - an event that places the focus on those within a group and reinforces the lines that distinguish the members of the group from those of other groups (Malina 1986:21-22; see Esler 2003:210-211; Groenewald 2005:143-145). Ceremonies are predictable and occur regularly; they are determined, called for and presided over by officials; and they function to confirm roles and statuses within the chief institutions of the group (Neyrey 1991:362-363).

The earliest followers of Jesus separated themselves from their 'parent body', the House of Israel, to find their own identity (see Collins 1989:38-39). To symbolise their entrance into their new group (the 'family of God') as a legitimate crossing of a boundary, baptism served as the ritual of initiation and transformation of status in the context of the earliest Jesus-groups (cf. Turner 1987:380-383, 386; see Groenewald 2005:169-236). Members of this 'new' community practiced a new lifestyle. This was symbolised by their participation in the Eucharist, which can be termed an all-inclusive ceremony of integration (Theißen 1999:121).

Extensive research has already been carried out on the origins of the Eucharist. Research, however, has not indicated whether this ceremony of participation could be newly explained by taking the contemporary knowledge of alternate states of consciousness ${ }^{4}$ into consideration.

\section{Alternate states of consciousness}

Alternate states of consciousness can be described as qualitative and quantitative alterations in the overall pattern of mental functioning relative to some state of consciousness chosen as a baseline, so that a person will experience his or her consciousness as different from the way it functions in the baseline state (Erickson \& Rossi 1981:242, 248; Pilch 2004:2; Tart 2000:257). Erika Bourguignon (1979:236) defines alternate states of consciousness as:

conditions in which sensations, perceptions, cognition and emotions are altered. They are characterized by changes in sensing, perceiving, thinking and feeling. They modify the relation of the individual to self, body, sense of identity, and the environment of time, space or other people.

(cf. Krippner 1972:1; Ludwig 1966:225, 1972:11)

Whatever is experienced as the baseline state of consciousness in any given cultural setting is a construct and not a given.

4.I choose to use the term 'alternate' states of consciousness, because, as Zinber (1977:1, n. 1) comments, it is a 'plural, all-inclusive term'.
Our levels of consciousness change constantly throughout the day. Cultural forces select and prescribe from the broad spectrum of human potentialities those elements which are to be described as 'normal/ordinary' (Craffert 2002:66-67; Tart 1982:245; see Lewis 1989:5).

In the light of social-scientifically oriented studies, we know on account of cross-cultural anthropological investigations that only ten percent of people all over the world today do not experience common alternate states of consciousness, whilst the rest of humanity do (Bourguignon 1974:229-232; Pilch 2002c:33-34).

Research demonstrates that the premodern mythical world of the biblical period stands in continuity with this finding - people who lived in the 1st century Mediterranean world experienced alternate states of consciousness as an ordinary part of life (see Bourguignon 1974:232, 1979:236; Pilch 1996a:133). Only in the Eurocentric world have we - the ten percent exception to the rule - started to interpret the Eucharist as a cognitive dogmatic construct (cf. Kleinman 1988:50-51).

\section{Anti-language}

In our contemporary context we can perform empirical research into the experience of individuals. But it is not possible to determine what individuals experienced 2000 years ago when the earliest followers of Jesus developed their Eucharistic rites.

My hypothesis is that the participation, ritually expressed by the 'sacrament' of the Eucharist, can be 'better' explained ${ }^{5}$ against the background of alternate states of consciousness.

This anthropological phenomenon termed alternate states of consciousness has recently been applied to biblical studies, pioneered by John J. Pilch (1981-2004). However, research into alternate states of consciousness creates a theoretical problem because, even though these states can be experienced simultaneously by more than one person in a group, experiences of alternate states of consciousness represent individual, mental, psychological states (cf. Lewis 1989:5; Richeport 1984). In other words, without empirical evidence of what an individual has really experienced during an alternate state of consciousness, research is jeopardised, because of the impossibility of ascertaining the religious meaning and value attributed to a specific alternate state of consciousness experience. Yet, we do have texts as well as archaeological and paleontological findings which show that there is a correlation between alternate states of consciousness and a participation in the 'dying and rising' of

5.Van Huyssteen (1988:88) remarks that explanatory progress in theology points to an increase in intelligibility. This is the reason why epistemologically I explain 'progress' in science in terms of the words 'explanation' and 'better' Van ' Huyssteen 'progress' in science in terms of the words 'explanation' and 'better'. Van Huyssteen (1988:88) says: 'Explanatory progress, as a form of inference from the best available explanation in terms of either hermeneutical, theological or philosophical criteria, can therefore indeed be established retrospectively by indicating how a late interpretation improves on its predecessors - and because of the reality depictio of theological statements this need not be an instrumentalist or pragmatist notion of progress.' 
deities, symbolised by 'blood' ceremonies such as enactments of sacrificial atonement.

This, I propose, can be seen in the 'anti-language ${ }^{6}$ utilised by the first Jesus-groups. Anti-language is the language that is used by an anti-society, which, in turn, can be described as a conscious alternative to another society (Halliday 1976:570 584, 1986:164-182; see Groenewald 1995:31-39). The earliest Jesus-followers formed an anti-society, into which they were initiated by means of baptism and in which they participated by means of the Eucharist.

The earliest followers of Jesus wished to say something about Jesus' alternative lifestyle, which they re-enacted. The lifestyle he advocated differed in many ways from the norms and the customs of the day. Jesus proclaimed that to be a part of the kingdom of God was the opposite of being a part of the kingdom of Caesar (Van Aarde 2000:10; cf. Elliott 2002:86; Koester 1992:10-13; Malina 2001:1). Because the earliest Jesus-followers were marginalised by the Israelite parent body (with its hierarchical temple structure and sacrifice tradition), as well as by the Roman Empire (where recognition was to be given to Caesar, who was perceived as a deity, in every activity and where refusal was interpreted as treason) (see Barr 1998:127, 164-179), they formed an alternative community with an apocalyptic worldview. ${ }^{7}$ Since apocalypticism has to do with the revelation of God's alternative world in the real world, it can be seen as an alternate state of consciousness phenomenon. The earliest followers of Jesus projected a better future promised by God - a promise that functioned in their present circumstances as a kind of coping mechanism.

Because of the 'institutionalisation' of the alternate states of consciousness of the earliest Jesus-followers, an alternative community was formed. Although it is difficult to study alternate states of consciousness because of their psychological individuality, the result of experiencing them - the formation of an alternative community - can be studied much more easily because of its empirical appearance and externally witnessed evidence.

\section{Method}

My point of entry is that of current research, which indicates that the Eucharist can be seen as a symbolic rite. As with

6. Halliday (1986:165) indicates that the simplest form taken by an anti-language is that of substitutin that of substuting new works folised. Usually a different vocabulary is central to the distinguishes it sharply from the established society. But anti-language is not merely relexicalised, it is also overlexicalised. If we examine the language of the earliest Jesus-followers, Malina and Rohrbaugh (1998:4-5) indicate that these two linguistic phenomena can be easily recognised. If we keep the theme of this article in mind, an example of relexicalisation can for example be seen in the terminology associated with the Eucharist. To call bread 'the body of Christ' or wine the 'blood of Christ' is to employ instances of relexicalisation. Relexicalisation usually points to items and objects affecting areas of central concern to the group. Overlexicalisation can for instance be seen in the 'I am...' statements of Jesus, for example 'bread' (Jn 6:35) and 'door' (Jn 10:9). These words have the same denotation in the context in which they are employed; they refer to real objects. However, when identified with Jesus in an 'I am...' proposition, each takes on an interpersonal dimension. Jesus is not bread, but he is like bread for those who stay attached to him; he is not a door, but he is like a door to God for those who believe in him (Malina \& Rohrbaugh 1998:5-6).

7.Apocalyptic thinking comes to the fore when religious people feel that they cannot alter their unbearable circumstances by themselves. Then they reach out to God for help. They believe that God will soon bring an end to this wicked world and call a righteous world into existence (cf. Rist 1989:157; Van Aarde 1994b:79-80). other symbols, the earliest Eucharist carried meaning because it was performed for a reason and it added value to people's lives (cf. Beattie 1968:69-70).

Subsequently, my purpose is to indicate that the earliest Eucharist, as the institutionalising of a ceremony of open table fellowship, symbolised an alternative lifestyle within 'baseline consciousness'. It bore meaning for one's social life in the here and now experiences of the earliest Jesus-groups.

I intend to argue that the ceremonial participation of the earliest Jesus-followers was the result of alternate states of consciousness as expressed in anti-language. I aim at redirecting extant research concerning the origins of the 'Christian' Eucharist by means of a multidisciplinary methodological approach. The importance and relevance of this research are found in the enhancement of social inclusivity as an ideal in the present day.

The method I wish to employ is as follows: I shall firstly give attention to the reason why the earliest Jesusfollowers participated in the Eucharist, which will entail an examination of the foundation of the earliest Eucharist. Then I shall discuss the value that participation in the Eucharist added to the lives of the earliest Jesus-followers, which will encompass an examination of Eucharistic formulae for traces of anti-language. Lastly, I shall examine the meaning entailed in participation in the Eucharist for the earliest Jesus-followers, which will further entail a discussion of holy meals as cultural, ceremonial symbols.

\section{Reason: Foundation of the earliest Eucharist Introduction}

Did Jesus of Nazareth establish the Eucharist? This question has been posed over many years by different scholars (see e.g. Bultmann 1984:152-153; Feld 1976:4-39; Lietzmann 1967; Lohmeyer 1937:204-223, 1938:92-94). I want to propose that the 'foundation' of the Eucharist probably lies in the last meal of Jesus with his disciples, as well as in the other meals Jesus had.

\section{Foundation of the Eucharist in the meals Jesus had}

Bradshaw (2002:61-62) observes that one of the major difficulties faced by scholars with regard to the origins of the Eucharist is the question regarding to what extent the accounts of the Last Supper in the New Testament (Mt 26:1730; Mk 14:12-26; Lk 22:7-38; 1 Cor 11:23-26) can be treated as reliable descriptions of an actual historical event and how far

Summary:
$\begin{aligned} & \text { Historical Jesus } \\ & \text { 'show' } \\ & \text { alternate states of } \\ & \text { consciousness }\end{aligned}$
$\begin{aligned} & \text { 'tell' } \\ & \text { anti-language }\end{aligned}$

FIGURE 1: Summary of method employed in article. 
they have been affected by the later liturgical practices of the first generation of 'Christians'.

Theißen (1999:130) states that Jesus' 'Last Supper' was preceded by other communal meals which contained a symbolic surplus of meaning and that there is a possibility that at his Last Supper Jesus made a connection between his death and the supper. We see this in the 'words of institution'. But the reference to Jesus' death could have been created after Easter (on the basis of his execution, which had taken place in the meantime). This link can also be perceived in the Pauline variant of the words of institution, where the Last Supper is associated with the promise of the new covenant, which has nothing to do with sacrifices (Theißen 1999:130).

Funk and the Jesus Seminar (1998:141-142; cf. Crossan 1992:360-367) contribute to this discussion by concluding that the Last Supper as depicted in Mark 14:22-26 was probably not an historical event. On the other hand, they acknowledge that, since Jesus ate frequently with his followers, there must have been $a$ last meal with them.

Crossan (1994:178) further points out that, if Jesus himself had ritualised a meal in which he identified bread and wine with his body and blood, it would be difficult to explain the absence of such symbolisation in Eucharistic texts like Didache 9-10. This leads Crossan (1994:178-179) to conclude that it was open commensality ${ }^{8}$ during Jesus' life, rather than the Last Supper before his death, that was the root of any later ritualisation.

\section{Crossan (1994) says:}

The kingdom of God as a process of open commensality, of a nondiscrimination table depicting in miniature a non-discrimination society, clashes fundamentally with honor and shame, those basic values of ancient Mediterranean culture and society.

(Crossan 1994:70)

For Jesus' contemporaries, with their group-centred personalities, the:

idea of eating together and living together without any distinctions, differences, discriminations, or hierarchies is close to the irrational and absurd. And the one who advocates or does it is close to the deviant and the perverted. He has no honor. He has no shame.

(Crossan 1994:70; cf. Van Staden 1991:224-229)

Perrin (1967:102-108) views the tradition that Jesus offered table fellowship to outcasts as historical (Mt 11:16-19). He considers that Jesus' table fellowship utilised the symbolism

8.Crossan (1994:68) defines the word 'commensality' as 'the rules of tabling and eating as miniature models for the rules of association and socialization', from the Latin word mensa which means table. According to him commensality refer to table fellowship as a map of economic discrimination, social hierarchy and political differentiation. Crossan (1994:66-69; cf. Scott 1990:161; Van Bruggen 1994:388-392) uses the parable in Matthew 22:1-13, Luke 14:15-24 and in the Gospel of Thomas 64, in which a person hosts a feast, sends a servant to invite his friends, but all the friends make excuses and then the host replaces the absent guests with anyone from the street, as an example. This could lead to a situation guests with anyone from the street, as an example. This could lead to a situation in which classes, genders and ranks could be mingled - anyone could be reclining next to anyone else. This, according to Crossan (1994:69), is open commensality - 'an eating together without using table as a miniature map of society's vertica discriminations and lateral separations'. Since Jesus lived out this parable, he was called a glutton, drunkard, friend of tax collectors and sinners (Mk 2:18-20 Mt 11:18-19; Lk 7:33-34). This suggests that Jesus did not make 'appropriate' distinctions and discriminations. of the messianic banquet, as defined in Matthew 8:11. He perceives these texts as authentic to the historical Jesus, because they represent perspectives more appropriate to Jesus' setting than to that of the 'early church'. Perrin indicates that Jesus' table fellowship explains how he came to die: his actions defiled the boundaries of the community and thus functioned as an act of such offensiveness to Israelite sensibilities that the leaders of Israel called for his death. He asserts that this also explains how the earliest Jesus-groups came to eat a communal meal together; a practice that came into existence so early that it must have been a continuation of the practice of Jesus himself.

Perrin (1967:104-105) adds that the practice of communal meals amongst the earliest Jesus-followers existed long before there was a specific 'Christian' theology to accord it meaning. In his opinion we cannot argue that the meals are an echo of the 'Last Supper' held by Jesus with his disciples during the Passion, because, even if such an occasion as is reported in the Gospels is historical, it did not, in itself, give rise to the 'early Christian' practice. All of our evidence indicates that the kind of theological emphasis associated with the 'Last Supper' in the Gospels was by no means the major emphasis in the communal meals of the earliest Jesus-followers. He also argues that these early communal meals did not originate in the religious practice of ancient Israel, the reason being that the Passover meal was a yearly affair. The Qumran communal meal anticipating the 'messianic banquet' could also not have constituted the origin of the communal meals amongst the earliest Jesus-followers, because this was simply a special significance accorded to the regular communal meal at Qumran. The earliest Eucharist was something out of the ordinary which the earliest followers of Jesus enacted and which helped to give them a special identity. The most reasonable explanation is thus that the communal meals of the earliest Jesus-followers are a continuation of a regular practice of the ministry of Jesus.

\section{Theißen (1999) likewise holds that the:}

Eucharist came into being from the meals that Jesus held. In remembrance of the last supper it is related to the death of Jesus. And this death of Jesus in turn takes the place of the ancient sacrifices.

(Theißen 1999:124)

In other words, Theißen's (1999:126; cf. Hooker 1997) thesis is that the Eucharist originated from the prophetic symbolic action with which Jesus delivered his 'eschatological' message (in opposition to the traditional rites). Only by its reference to the death of Jesus could this symbolic action become an early 'Christian' sacrament, because this reference gave it the power to supersede the traditional sacrifices.

\section{Jesus' 'showing' in his meals}

In this section I argued that the foundation of the Eucharist can be found in the symbolic meals that Jesus of Nazareth shared with other people ('showing'). Jesus had an alternative view of the world, which he displayed by means of inclusive meals, in which anyone could share, here and now. But to be a part of this world of Jesus, which can be termed the 
'kingdom of God', whilst at the same time still living in the ordinary world, called for alternate states of consciousness. In the next section, the 'telling' of the earliest Jesus-followers will be described.

\section{Value: Eucharistic formulae as anti-language}

\section{Introduction}

In this section I explore the possibility that the ritualisation of the earliest Eucharist is a verbalisation, in anti-language, of an alternate state of consciousness. I will examine Eucharistic formulae in the New Testament and other early Christian literature, in order to show that anti-language is recognisable in what was said around the Eucharistic table. To say that you eat the body of Christ and drink the blood of Christ, whilst in practice you are eating bread and drinking wine, is nothing else than making use of the rich symbolism of anti-language. I will also undertake a cursory examination of similarities between the earliest Eucharist and the GraecoRoman mystery religions, since this should help to highlight the role that alternate states of consciousness, as expressed in anti-language, played in the earliest Eucharist. In other words, this section of the article will be devoted to the earliest Jesus-followers' 'telling'. They started to 'tell' other people what Jesus 'showed' in his meals, because it added value to their lives.

\section{Eucharistic formulae in the New Testament}

A close look at Eucharistic formulae in the New Testament should make the use of anti-language apparent. The texts I refer to only serve as illustrations; I do not intend to provide a comprehensive overview of all the available Eucharistic texts.

The first example comprises the miraculous multiplication of loaves (Mk 6:30-44//Mt 14:13-21//Lk 9:10-17//Jh 6:1-14; Mk 8:1-10//Mt 15:32-39). ${ }^{9}$ Anti-language can be perceived in the disciples' misconception that there was not enough bread to feed everyone - Jesus made sure that every single person could be fed. In the family of God no-one has to be sent away or remain hungry.

A second example narrates the story of the walk to Emmaus (Lk 24:13-32). ${ }^{10}$ The two disciples walk on the road - the 'way' is a codeword for the new religion. This constitutes an example of anti-language.

A third example is that of the meal described by Paul in 1 Corinthians 11:23-26 (the story of the 'Last Supper'). ${ }^{11}$

9.For an explanation of the meaning of these texts in the context of the Eucharist, see Van lersel (1964/65:189-190); Gerhardsson (1979:56); Neyrey (1991:380); Van Aarde (1994a:195).

10.Scholarly debate exists regarding whether this passage should be understood in the context of the Eucharist, or not (see Grundmann 1971:442-448; Schmithals 1980:234-235; Moessner 1989:178; Stevenson 1989:45; Nolland 1993:1206; Crossan 1994:170-174)

11.According to Smith (2003:189-191; cf. Mack 1988:116-119), the description of the 'Last Supper' evokes several banquet models. It contains overtones of the funerary banquet, the memorial meal and the messianic banquet. He says that the terminology that is used denotes that the meal functions in a ritual context, most probably a sacrificial one, but sacred meals are merely variations on the generic probably a sacrificial one,
Graeco-Roman banquet.
Numerous examples of anti-language occur in this passage. That Jesus refers to bread as his body and wine as his blood is probably the most obvious examples of anti-language found in all of the texts.

A fourth example comprises John's description of the last supper that Jesus and his disciples ate together (Jn 13:1-17:26), a version that differs from the description of the Last Supper in the Synoptic Gospels. It is not a Passover meal and there are no references to any words of Jesus being uttered over bread and wine. But it is still a meal that refers symbolically to the death of Jesus and includes a command that the disciples should do as he has done (Jn 13:14-15). This supper is described in a parallel section to those in which the Last Supper is described in the other Gospels. But the interpretation of this meal is associated with a new ritual, the foot-washing, which indicates that the real significance of the shared meal is one of mutual service and mutual love (Theißen 1999:138; see Smith 2003:274). This is another example of Jesus 'showing'. Although John does not describe a traditional Last Supper scene, he does include words of Jesus pronounced over bread and wine in another text (Jn 6:53-54), but without offering a profound religious interpretation of the elements (Theißen 1999:138). The reference to 'eating flesh and drinking blood' refers to the radical boundary now drawn between the Johannine community and its neighbouring synagogue community. And this boundary is created by means of anti-language. From the point of view of the Johannine community (now no longer a synagogue community but rather a meal community), it is the meal that constitutes a new boundary marker between the two communities, effectively supplementing, if not replacing, the synagogue as the boundary marker (Smith 2003:275).

\section{Eucharistic formulae in non-Biblical texts}

According to Smith and Taussig (1990:15; cf. Thurian \& Wainwright 1983:111-115) the earliest texts that afford clear, unambiguous evidence for early forms of the liturgy of the Eucharist are not New Testament texts but those of the church fathers. This does not mean that the New Testament is not important in this regard, but it is considered to function in the form preserved in the church's traditional interpretation rather than as an independent witness in itself.

Many documents outside of the New Testament furnish an account of early Eucharistic practices, for example, the Didache, the writings of Justin Martyr and the Traditio apostolica of Hippolytus.

If we study these early texts describing the Eucharist, a faint picture emerges of how this ceremony might have taken place in the early days: Only baptised people could participate in the Eucharist. After baptism, members of the congregation exchanged the kiss of peace, expressing reconciliation with each other, to mark the beginning of the Eucharist, the joyful response to Christ, expressed in the celebration of the Lord's Supper (Justin, 1 Apol 65) (Oetting 1970:35).

The earliest celebrations of the Eucharist most probably took place in the setting of an actual meal, which is sometimes 
called the ớ ${ }^{\prime}$ me [love feast]. Each individual brought food, the congregation partook of it together, rich and poor alike and any food that was left over was given to the poor (see 1 Cor 11:18-22; Ignatius, c. 110). By the time of Justin Martyr (c. $150)$, the Eucharist $\mathrm{t}^{12}$ seems to have been celebrated separately (Oetting 1970:36-37).

Leavened bread was used and the wine was mixed with water. The deacons took the elements to the worshippers. In addition, the newly baptised were given milk and honey to symbolise that they were babies in Christ but also to show that they were now in the Promised Land, the land 'flowing with milk and honey'. Participants in the Eucharist believed that they received Christ's body and blood in the Eucharist (Irenaeus, Haer IV.xviii; V.ii).

\section{The Eucharist and the Graeco-Roman mystery religions}

Numerous similarities are evident between the earliest Eucharist and some of the Graeco-Roman mystery religions (Meyer 1987:226). To illustrate this point, I shall provide a cursory commentary on two examples of mystery religions in this section. My purpose is to emphasise the important role that alternate states of consciousness, as well as their verbalisation in anti-language, played in these rites.

My first example comprises the mystery religion in honour of the Greek god Dionysos, also called Bacchus. ${ }^{13}$ Alternate states of consciousness are displayed in the participants' roaming the forests and the mountains, clothing themselves in fawn skins and wielding thyrsi (Meyer 1987:63). The worshippers of Dionysos acknowledged his presence in the raw flesh of wild beasts, as well as the goblet of wine, in the phallus concealed in the liknon (a winnowing basket that might be used as a cradle for a baby) and also in the immortal human soul. A person who was confronted by the presence of Dionysos and became possessed by him could feel his power in many different ways: in ecstasy, in inebriation, in sexuality, or in spiritual bliss. Such a person became one with Dionysos and could even be called Bacche (feminine) or Bacchos (masculine) after the god himself. Little is known of the actual mysteries of Dionysos, but it appears that they usually included eating and drinking. In the archaic mysteries, the initiates were said to tear animals to pieces and eat the flesh raw, as a way of assimilating the Dionysian power embodied within the animal. In more serene rites, the meal was a banquet. The holy drink was ordinary wine, the gift of the god.

There is a very clear resemblance between this mystery religion and the earliest Eucharist, especially in the eating of the 'flesh' of the god and the drinking of wine, which was sometimes called 'blood so sweet' (Meyer 1987:93-94).

12.'The celebration of the Lord's Supper gets the name "Eucharist" from the praye of thanksgiving that was said over the offerings [of food for the poor] as Justin suggests" "tha " man, for delivering us from the sin in which wr creating everything for the sake of dominions and powers through Him who suffered"' (Dial 14 - see Oetting 1970:37).

13.See Meyer (1987:63) and Finegan (1989:172-173) for a description of what this mystery religion entailed.
My second example stems from the mystery religion in honour of Mithras. ${ }^{14}$ The men devoted to Mithras entered the Mithraea, designed as caves and participated in various purifications, initiatory rites and ceremonial meals. Justin Martyr (Apol 66.4) records that the initiates took bread and a cup of water (or a cup of mixed water and wine - these elements may have been symbolic of the body and blood of the bull) and uttered certain formulas at a holy meal. The purpose of the Mithraic rituals was to effect salvation and transformation (Meyer 1987:199-200).

Once again the parallel with the earliest Eucharist is easily recognisable, especially in the ceremonial meals, in which the elements probably symbolically depicted the body and blood of the bull.

These similarities are explicable in terms of the shared milieu of the Graeco-Roman world (Meyer 1987:226). People participated in the mystery religions because the latter enriched their lives, just as participation in the Eucharist added value to the earliest Jesus-followers' lives. The important role that alternate states of consciousness played in rites can perhaps be perceived more easily in the mystery religions than in the earliest Eucharist - this reinforces my theory that in the early Mediterranean world, alternate states of consciousness were part and parcel of ceremonies and that anti-language was used to verbalise these states (cf. Burkert 1987:114).

This concludes the present section regarding the 'telling' of the earliest Jesus-followers. The word about Jesus' way of life, as illustrated in his open commensality, spread fast, because it added value to believers' lives. Because participation in the Eucharist was an extraordinary event and because the Eucharist acted as the integration ceremony of an antisociety, ordinary language was not adequate to illustrate the way it enriched participants' lives; therefore anti-language was employed. To be a part of early Jesus-groups imparted meaning to believers' lives; they expressed this meaning by 're-enacting' what they were 'told' Jesus had 'showed', by means of participating in the symbolic integration ceremony they called the Eucharist. In the next section this 're-enactment' and the meaning it gave to their lives, will be discussed.

\section{Meaning: Holy meals as a cultural ceremonial symbol of integration into an alternative society Introduction}

As indicated earlier, the earliest Jesus-followers formed an anti-society. People became members of this society because membership gave meaning to their lives; and membership was imparted by means of baptism. Once they had become members, the Eucharistic table was the occasion where

14.See Betz (1986:336), Meyer (1987:199) and Finegan (1989:203-209) for a description of this mystery religion. 
they demonstrated their solidarity with one another. Hence the Eucharist can be termed a ceremony of integration (see Theißen 1999:121). The Eucharist can be described as a 'reenactment' of Jesus' open commensality.

\section{The Eucharist as ceremony of integration}

The function of ceremonies is to co-ordinate life in communities. According to Theißen (1999:122-123), this process took place mainly through sacrifices (see Hanson 1979:28), especially where these were connected with shared meals. This leads Theißen to conclude that the earliest Eucharist was a ceremony of integration, which was constantly repeated and renewed the cohesion of the community, especially because it replaced the earlier sacrifices (cf. Koch 2001:239; Meier 1997:267; Pilch 1996c:9596).

As a rule, rites are ancient and have been practiced since primal times. In contrast, the Eucharist is a new rite, because it originated with a charismatic figure of the recent past - Jesus (see Theißen \& Merz 1996:359-360). To Theißen (1999:126), 'Jesus provided the stimulus for the eucharist by associating with his person at his last supper...meals which were held repeatedly'. The meals that Jesus hosted originally were prophetic symbolic actions (i.e. patterns of action focused on a unique situation, in order to convey a message) (cf. Pilch 1981:109, 1996c:95-96). The unique situation of these meals encompassed the fact that they were held in the face of the imminent end of the world and that they could not be separated from their founder. Their message proclaimed that God's salvation is made present through fellowship with toll collectors and sinners - with a view to the 'eschatological' feast in the kingdom of God to which all people will stream from all over the world (Theißen 1999:126-127).

Theißen (1999:127) therefore concludes that the Eucharist is a threshold ritual, which opens the way to a new world. Jesus held his meals in anticipation of the eschatological feast in the kingdom of God (Mk 14:25). In threshold rituals we find an anti-structure to the traditional forms of life: 'In celebrating a meal with his disciples in Passover week...to which he gives a special significance by words of interpretation, Jesus is implicitly, perhaps even deliberately, constructing an alternative to the temple ritual' (Theißen 1999:27; see Theißen \& Merz 1996:380-383).

\section{To Theißen (1999):}

the earthly Jesus' acceptance of the sinner at table on an equal footing now becomes possible-after his death and in his absence - by a reference to his 'dying for us' (and by the conviction of his mysterious presence at the eucharist as the risen Christ).

(Theißen 1999:130)

Here once again is evident the importance of alternate states of consciousness, because this was the way in which the risen Christ could be experienced as present at the Eucharistic table.

\section{The earliest Eucharist and alternate states of consciousness}

As I suggested earlier, participation in the earliest Eucharist implied the experience of alternate states of consciousness. The notion of eating together with gods or spirits is found in many cultures. The idiom of commensality is one of mutual respect and good will; sharing food or drink with a ghost or spirit, as with anybody else, implies amity and, especially, reconciliation (Beattie 1968:234).

Jesus claimed that he could already enter the kingdom of God and that the kingdom of God could already be realised for people who lived their lives as he did (Crossan 2003:49). This was symbolised by participating in the Eucharist. The Eucharist made the kingdom of God a reality in the present lives of the participants. We should keep in mind that the earliest Jesus-followers adopted an apocalyptic worldview (see Marxsen 1979:107-108; Van Henten \& Mellink 1998:12). In the practice of the earliest Jesus-followers, of regularly celebrating the 'Last Supper' until Christ would return ('in memory of Christ'), this apocalyptic worldview is foregrounded. By doing this, they experienced 'another' time, the time of God, as breaking into ordinary time. This is nothing else than the experience of an alternate state of consciousness.

We know that sharing the same cup implied sharing in the meaning of that cup as well (as in the Israelite Passover tradition). This is why Jesus asked God to let the cup pass him by in Gethsemane (Mk 14:35-36), because he knew what this image implied (cf. Smith 2003:251; see Bolkestein 1977:328-329). The two disciples (Mk 10:35-40) did not understand the implication of their request to sit at the left and right hand side of Jesus in his glory (Bolkestein 1977:237240). The second most important person (after the host) always sat at his right-hand side and was required to drink first. The implication of this is that, if one drinks from the cup at the Eucharistic table, one shares in Jesus' fate, since the cup is placed in conjunction with the cross. But by choosing to die, one in actual fact gains life. All of this makes sense if understood from an apocalyptic perspective, in conjunction with alternate states of consciousness and anti-language.

By means of taking part in the Eucharist, the earliest Jesusfollowers thus already participated in the kingdom of God. Since the world around them was continuing its natural course, this experience must have taken place in alternate states of consciousness.

\section{Anti-society and the earliest Eucharist}

The earliest Jesus-followers formed an anti-society, structured on the basis of a fictive kinship. If we bear in mind that Jesusmovements were already characterised by great diversity at a very early stage (Pelser 1987:557), we need to ask the question how a sense of cohesion could develop so easily. How could individuals from diverse ethnic, religious and social backgrounds come to call one another 'brothers and sisters'? How were these bonds created and experienced? Smith (2003:184) theorises that the most likely locus for this 
development is the community meal, with its unparalleled power to define social boundaries and create social bonding.

Smith (2003:184-185) suggests that we see this development taking place especially in Paul. The meal had already become a focus for communal identity prior to Paul. To meet for a meal was a natural thing to do and to develop social bonds as a result was expected. But soon there developed a distinctive theological rationale for the community meal it came to be defined as a memorial feast commemorating the death of Jesus. This was the shape of the meal that Paul inherited. Smith (2003:184-185) also writes that, with this development, a 'new wrinkle' was taking shape with the wholesale inclusion of Gentiles in the Jesus-groups. Up until this point, the 'people of God' had been the people of Israel and their status was indicated by the boundary markers of circumcision and some level of adherence to laws of purity. As long as the community was drawn primarily from an Israelite and proselyte constituency, these boundaries could still be assumed. But when Gentiles began to claim community membership as Gentiles, something new was starting to occur. How could Gentiles come to believe that they were part of God's people without being circumcised? This process had begun with the initiation rite of baptism. But Smith (2003:185; cf. Elliott 1991:387) illustrates that it was participation in the meal that provided the catalyst for this development. It was the meal that created a sense of belonging, of social bonding with the community.

\section{The meaning of Jesus' open commensality}

What did the Eucharist signify for the earliest followers of Jesus? De Jonge (2001:210; cf. Danker 2000:415; Pelser n.d.:167) considers that the purpose of the community meal was the realisation of the communion [kolvwvia] which the members of the congregation felt they missed in the outside world. They believed that Christ was present in the meal and they prayed that they would be united with one another and with Christ and would share in the joys of eternity (Stevenson 1989:62-63). In the Eucharist the whole community thus participates in the death and resurrection of Christ (Cullmann 1969:29-30).

Table fellowship was very important amongst the cultures of the Mediterranean basin in the 1st century: Mealtimes were 'laden with meanings' that exceeded consumption of food (Bartchy 2002:175). Being welcomed at a table to eat with another person was a ceremony richly symbolic of friendship, intimacy and social unity. The context within which meals were consumed comprised the extended family. Beyond the household, people preferred to eat with persons from their own social class. Invitations to meals were given to people with the same social, religious and economic status, in order that the invited person could return the favour in a relationship of balanced reciprocity.

Bartchy (2002:176; see Douglas 1972:79-80) contends that everyone in the 1st century Mediterranean world would expect that meals would constitute exclusive occasions in which honour was given to those to whom honour was due. In contrast to this, Jesus did exactly the opposite. For him honour was still a key value, but he made honour by birth and acquired honour irrelevant: he bestowed everyone (without regard for social status, personal accomplishment, purity or health) with honour in the name of Israel's God. Instead of seeking honour for himself, Jesus was prepared to be humiliated. For him, in contrast to the popular understanding, honour was not in limited supply. His God offered an unlimited supply of honour; in turn, those honoured by God possessed the social resources to accord honour to others without fear of diminishing their own. Non-retaliation thus became the only honourable response to a challenge to one's personal honour. Meals became an especially prominent occasion for this outrageous giving of honour to all, around a radically inclusive table (Bartchy 2002:181-182).

In conclusion, the two basic ethical values amongst the earliest Jesus-followers, according to Theißen (1999:63), were love of neighbour and renunciation of status. Since everybody who believed in Christ and was baptised could participate in the Eucharist on an equal level, the Eucharist could be viewed as the place where the 'early Christian' ethic was lived out.

\section{Conclusion}

In this article I have attempted to demonstrate that the earliest Eucharist represented an anti-language verbalisation of alternate states of consciousness. By participating in the Eucharist, the earliest followers of Jesus experienced the presence of God amongst them. They spoke about this experience in anti-language, since ordinary language was not adequate to verbalise such an extraordinary experience. All of this exerted a lasting effect on their lives - they lived according to the example Jesus set, because they believed that they participated in his death and resurrection. They were now part of a new family. The earliest Jesus-followers shared a special relationship with each other, as well as with Jesus (in alternate states of consciousness) and they illustrated this by means of the ceremony of the Eucharist.

The reason why the earliest Jesus-followers placed a strong emphasis on participating in the ceremony of the Eucharist, was that Jesus 'showed' them what it was like to be part of the kingdom of God, by means of the meals in which he participated. The earliest Jesus-followers 'told' this to others, by means of anti-language, which we can trace back to early texts bearing witness to the earliest Eucharist, because of the value which participation in the Eucharist added to their lives. Then early Jesus-groups 're-enacted' what they had been told by means of the ceremony of the Eucharist, because the latter gave meaning to their lives. Although they were persecuted, they apocalyptically experienced the presence of God directly in their lives, by means of alternate states of consciousness. This experience changed their lives, because they now lived according to a new ethic, as 'brothers and sisters' in faith. 
At the beginning of the article I expressed the hope that this study might assist us in realising once again what kind of value the Eucharist can add to our lives today, especially since institutionalised churches are entering a phase of deinstitutionalisation and this ceremony was developed before formative Christianity became an institution. Although the Eucharist still plays an important role in the liturgy of many Christian churches today, the spiritual dimension that was so important in the 1st century seems to be lacking in institutionalised churches within a Eurocentric context. The Eucharist symbolised an all-inclusive ethical lifestyle, whilst people today are excluded from the Eucharist on the grounds of not having fulfilled all the necessary 'liturgical requirements'. A Eucharist where 'Jew' and 'Greek', 'slave' and 'free', 'male' and 'female' cannot equally share in the body and blood of Christ, has the opposite effect to the original intention of the Eucharist.

The Eucharist represents the symbolic 're-enactment' of that which Jesus 'showed'. It is the re-experiencing of an alternative state. By one's participation in the Eucharist, the 'ordinary' world is interrupted by something out of the ordinary. That which Jesus experienced in his alternate state of consciousness, can also be experienced in this ceremony, namely that the kingdom of God is immanent, that it differs from the ordinary world and that people can share in it in an inclusive way. This was the case in Jesus' time and it can still be the case today, if we once again attach a similar meaning to the Eucharist as that which the earliest Jesus-followers did.

\section{References}

Barr, D.L., 1998, Tales of the end: A narrative commentary on the book of Revelation, Polebridge, Santa Rosa, CA.

Bartchy, S.S., 2002, 'The historical Jesus and honor reversal at the table', in W. Stegemann, B.J. Malina \& G. Theißen (eds.). The social setting of Jesus and the Stegemann, B.J. Malina \& G. Theißen (eds.), The
Gospels, pp. 175-183, Fortress, Minneapolis, MN.

Beattie, J., [1964] 1968, Other cultures: Aims, methods and achievements in Social Anthropology, Free Press, New York.

Berger, P.L., 1967, The sacred canopy: Elements of a sociological theory of religion, Doubleday, Garden City, NY.

Betz, H.D. (ed.), 1986, The Greek Magical Papyri in translation: Including the demotic spells, University of Chicago Press, Chicago, IL.

Bolkestein, M.H., 1977, Het Evangelie naar Marcus, Callenbach, Nijkerk. (De Prediking van het Nieuwe Testament)

Bourguignon, E., 1974, 'Cross-cultural perspectives on the religious uses of altered states of consciousness', in I.I. Zaretsky \& M.P. Leone (eds.), Religious movements in contemporary America, pp. 228-243, Princeton University Press, Princeton, NJ.

Bourguignon, E., 1979, Psychological anthropology: An introduction to human nature and cultural differences, Holt, Rinehart \& Winston, New York.

Bradshaw, P.F., 2002, The search for the origins of Christian worship: Sources and methods for the study of early liturgy, 2nd edn., Oxford University Press, Oxford.

Bultmann, R., 1984, Theologie des Neuen Testaments, 9. Aufl., Mohr, Tübingen.

Burkert, W., 1987, Ancient mystery cults, Harvard University Press, Cambridge, MA.

Collins, A.Y., 1989, 'The origin of Christian baptism', Studia Liturgica 19(1), 28-46.

Craffert, P.F., 2002, 'Religious experiences and/as (alternate) states of consciousness from a biopsychosocial perspective', in C.W. du Toit (ed.), Brain, mind and soul: Unifying the human self, pp. 53-97, Research Institute for Theology and Religion, UNISA, Pretoria.

Crossan, J.D., [1991] 1992, The historical Jesus: The life of a Mediterranean Jewish peasant, HarperSanFrancisco, San Francisco, CA

Crossan, J.D., 1994, Jesus: A revolutionary biography, HarperSanFrancisco, San Francisco, CA.

Crossan, J.D., 2003, 'The resurrection of Jesus in its Jewish context', Neotest 37(1), 29-57.

Cullmann, O., [1950] 1969, Baptism in the New Testament, transl. J.K.S. Reid, SCM, London.

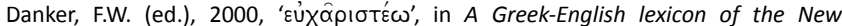
Testament and other early Christian literature, 3 rd edn., n.p., University of Chicago Press, Chicago, IL.

De Jonge, H.J., 2001, 'The early history of the Lord's Supper', in J.W. Henten \& A. Houtepen (eds.), Religious identity and the invention of tradition: Papers read at a Noster Conference in Soesterberg, January 4-6, 1999, pp. 209-237, Royal Van Gorcum, Assen.

Douglas, M., 1972, 'Deciphering a meal', Daed 101, 61-81.

Dreyer, Y., 2004, 'A public practical theological theory for religious education of secularised youth', HTS Teologiese Studies/Theological Studies 60(3), 919-945.

Elliott, J.H., 1991, 'Household and meals versus the Temple purity system: Patterns of replication in Luke-Acts', HTS Teologiese Studies/Theological Studies 47(2), 386-399.

Elliott, J.H., 1995, 'The Jewish Messianic movement: From faction to sect', in P.F. Esler (ed.), Modelling early Christianity: Social-scientific studies of the New Testament in its context, pp. 75-95, Routledge, London.

Elliott, J.H., 2002, 'Jesus was not an egalitarian: A critique of an anachronistic and idealist theory', Biblical Theology Bulletin 32(2), 75-91. doi:10.1177/014610790203200206

Erickson, M.H. \& Rossi, E.L., 1981, Experiencing hypnosis: Therapeutic approaches to altered states, Irvington, New York.

Esler, P.F., 2003, Conflict and identity in Romans: The social setting of Paul's letter, Fortress, Minneapolis, MN.

Feld, H., 1976, Das Verständnis des Abendmahls, Wissenschaftliche Buchgesellschaft, Darmstadt.

Finegan, J., 1989, Myth and mystery: An introduction to the pagan religions of the biblical world, Baker Book House, Grand Rapids, MI.

Fox, M., 1990, 'A mystical cosmology: Toward a postmodern spirituality', in G.R. Griffin (ed.), Sacred interconnections: Post modern spirituality, political economy, and art, pp. 15-33, State University Press of New York, Albany, NY.

Funk, R.W. \& the Jesus Seminar, 1998, The acts of Jesus: The search for the authentic deeds of Jesus, HarperSanFranscisco, San Francisco, CA.

Gerhardsson, B., 1979, The mighty acts of Jesus according to Matthew, Gleerup, Lund. (Scripta Minora 5).

Groenewald, J., 2005, 'Baptism, Eucharist, and the earliest Jesus-groups - from the perspective of alternate states of consciousness', DD dissertation, New Testament perspective of alternate states
Studies, University of Pretoria.

Grundmann, W., 1971, Das Evangelium nach Lukas, 6. Aufl., Evangelische Verlagsanstalt, Berlin.

Halliday, M.A.K., 1976, 'Anti-languages', American Anthropologist 78(3), 570-584. doi:10.1525/aa.1976.78.3.02a00050

Halliday, M.A.K., [1978] 1986, Language as social semiotic: The social interpretation of language and meaning, Edward Arnold, London.

Hanson, R.P.C., 1979, Eucharistic offering in the early church, Grove Books, Bramcote.

Hooker, M.D., 1997, The signs of a prophet: The prophetic actions of Jesus, SCM, London.

Kleinman, A., 1988, Rethinking psychiatry: From cultural category to personal experience, Free Press, New York.

Koch, D.-A., 2001, 'The early history of the Lord's Supper: Response to Henk Jan de Jonge', in J.W. van Henten \& A. Houtepen (eds.), Religious identity and the invention of tradition: Papers read at a Noster Conference in Soesterberg, January 4-6, 1999, pp. 238-252, Royal Van Gorcum, Assen. Koester, H., 1992, 'Jesus the victim', Journa of Biblical Literature 111(1), 3-15.

Krippner, S., 1972, 'Altered states of consciousness', in J. White (ed.), The highest state of consciousness, pp. 1-5, Doubleday, Garden City, NY.

Lewis, I.M., 1989, Ecstatic religion: A study of shamanism and spirit possession, 2nd edn., Routledge, London.

Lietzmann, H., [1955] 1967, Messe und Herrenmahl: Eine Studie zur Geschichte der Liturgie, 3. Aufl., De Gruyter, Berlin.

Lohmeyer, E., 1937, 'Vom urchristlichen Abendmahl', Theologische Rundschau 9, 168-227.

Lohmeyer, E., 1938, 'Vom urchristlichen Abendmahl', Theologische Rundschau 10, 81-99.

Ludwig, A.M., 1966, 'Altered states of consciousness', Archives of General Psychiatry 15, 225-234.

Ludwig, A.M., 1972, 'Altered states of consciousness', in C.T. Tart (ed.), Altered states of consciousness, 2nd edn., pp. 9-22, Doubleday, Garden City, NY.

Mack, B.L., 1988, A myth of innocence: Mark and Christian origins, Fortress, Philadelphia, PA

Malina, B.J., 1986, Christian origins and cultural anthropology: Practical models for Biblical interpretation, John Knox Press, Atlanta, GA

Malina, B.J., 2001, The social gospel of Jesus: The kingdom of God in Mediterranean perspective, Fortress, Minneapolis, MN.

Malina, B.J. \& Rohrbaugh, R.L., 1998, Social-science commentary on the Gospel of John, Fortress, Minneapolis, MN.

Marxsen, W., 1979, The beginnings of Christology. Together with: The Lord's Supper as a Christological problem, transl. P.J. Achtemeier \& L. Nieting, Fortress, Philadelphia,

Meier, J.P., 1997, 'Dividing lines in Jesus research today: Through dialectical negation to a positive sketch', in J.D. Kingsbury (ed.), Gospel interpretation: Narrative-critical \& social-scientific approaches, pp. 253-272, Trinity, Harrisburg, PA. 
Meyer, M.W. (ed.), 1987, The ancient mysteries: A sourcebook. Sacred texts of the mystery religions of the ancient Mediterranean world, Harper \& Row, San Francisco, CA.

Moessner, D.P., 1989, Lord of the banquet: The literary and theological significance of the Lukan travel narrative, Fortress, Minneapolis, MN.

Neyrey, J.H., 1990, Paul, in other words: A cultural reading of his letters, Westminster Louisville, KT.

Neyrey, J.H., 1991, 'Ceremonies in Luke-Acts: The case of meals and table fellowship', in J.H. Neyrey (ed.), The social world of Luke-Acts: Models for interpretation, pp. 361-387, Hendrickson, Peabody, MA.

Nolland, J., 1993, Luke 18:35-24:53, Word Books, Dallas, TX.

Oetting, W.W., [1964] 1970, The church of the catacombs: The introduction to the surging life of the early church from the apostles to A.D. 250, based on firsthand accounts, Concordia, Saint Louis, MI. (CHS).

Pelser, G.M.M., n.d., 'Die nagmaal by Paulus - geestelike voedsel en drank?', HTS Teologiese Studies/Theological Studies 32(3\&4), 161-167.

Pelser, G.M.M., 1987, 'Temaprediking uit die Nuwe Testament', HTS Teologiese Studies/ Theological Studies 43(3), 556-565.

Perrin, N., 1967, Rediscovering the teaching of Jesus, SCM, London. (NTLi).

Pilch, J.J., 1981, 'Jeremiah and symbolism: A social science approach', Bible Today 19(2), $105-112$

Pilch, J.J., 1988, 'Interpreting Scripture: The social science method', Bible Today 26(1) 13-19.

Pilch, J.J., 1993, 'Visions in Revelation and alternate consciousness: A perspective from cultural anthropology', Listening: Journal of Religion and Culture 28(3), 231-244.

Pilch, J.J., 1995a, 'A window into the Biblical world: Burying the dead', Bible Today $33(5), 286-292$.

Pilch, J.J., 1995b, 'Illuminating the world of Jesus through cultural anthropology: A reflection on the contribution cultural anthropology can make to biblical interpretation and the catechetical enterprise', The Living Light 31, 20-31.

Pilch, J.J., 1995c, 'The transfiguration of Jesus: An experience of alternate reality', in P.F. Esler (ed.), Modelling early Christianity: Social-scientific studies of the New Testament in its context, pp. 47-64, Routledge, London.

Pilch, J.J., 1996a, 'Altered states of consciousness: A "kitbashed" model', Biblical Theological Bulletin 26(3), 133-138. doi:10.1177/014610799602600305

Pilch, J.J., 1996b, 'Book Review: Jesus the healer: Possession, trance, and the origins of Christianity', Theological Studies 57, 182.

Pilch, J.J., 1996c, The cultural world of Jesus: Sunday by Sunday, Cycle B, Liturgical Press, Collegeville, MN.

Pilch J.J., 1997a, 'Are there Jews and Christians in the Bible?', HTS Teologiese Studies/ Theological Studies 53(1\&2), 119-125.

Pilch, J.J., 1997b, 'Psychological and psychoanalytical approaches to interpreting the Bible in social-scientific context', Biblical Theological Bulletin 27(3), 112-116.

Pilch, J.J., 1997c, Book Review: Jesus the healer. Possession, trance, and the origins of Christianity, Biblical Theology Bulletin 27(2), 71-72.

Pilch, J.J. 1997d, The cultural world of Jesus: Sunday by Sunday, Cycle C, Liturgical Press, Collegeville, MN.

Pilch, J., 1998a, 'Appearances of the risen Jesus in cultural context: Experiences of alternate reality', Biblical Theological Bulletin 28(2), 52-60. doi:10.1177/014610799802800204

Pilch, J.J., 1998b, 'A window into the biblical world: Caves', Bible Today 36(1), 47-53.

Pilch, J.J., 1998c, 'A window into the biblical world: Walking on the sea', Bible Today 36(2), 117-123.

Pilch, J.J., 1999a, 'A window into the biblical world: Imaginary mountains in Matthew' Bible Today 37(3), 174-181.

Pilch, J.J., 1999b, 'A window into the biblical world: Desert and wilderness', Bible Today $37(4), 247-251$.

Pilch, J.J., 1999c, The cultural dictionary of the Bible, Liturgical Press, Collegeville, MN.

Pilch, J.J., 2000a, 'A window into the biblical world: Dreams', Bible Today 38(3), 174-178.

Pilch, J.J., 2000b, 'A window into the biblical world: Seeing God', Bible Today 38(4) 243-247.

Pilch, J.J., 2000c, Healing in the New Testament: Insights from medical and Mediterranean anthropology, Fortress, Minneapolis, MN.

Pilch, J.J., 2001,' A window into the biblical world: Snakes in the Hebrew Bible', Bible Today 39(4), 239-243.

Pilch, J.J., 2002a, 'Altered states of consciousness in the Synoptics', in W. Stegemann B.J. Malina \& G. Theißen (eds.), The social setting of Jesus and the Gospels, pp. 103-115, Fortress, Minneapolis, MN.

Pilch, J.J., 2002b, 'A window into the Biblical world: No thank you!', Bible Today 40(1) 49-53.
Pilch, J.J., 2002c, Ereignisse eines veränderten Bewusstseinszustandes bei den Synoptkern', in W. Stegemann, B.J. Malina \& G. Theißen (Hrsg.), Jesus in neuen Kontexten, pp. 33-42, Kohlhammer, Stuttgart.

Pilch, J.J., 2002d, 'Paul's ecstatic trance experience near Damascus in Acts of the Apostles', HTS Teologiese Studies/Theological Studies 58(2), 690-707.

Pilch, J.J., 2002e, 'The nose and altered states of consciousness: Tascodrugites and Ezekiel', HTS Teologiese Studies/Theological Studies 58(2), 708-720.

Pilch, J.J., 2003a, 'A window into the biblical world: A new sky and a new earth', Bible Today 41(1), 51-55.

Pilch, J.J., 2003b, 'A window into the biblical world: Consciousness, science, and the resurrection appearances', Bible Today 41(4), 254-258.

Pilch, J.J., 2004, Visions and healing in the Acts of the Apostles: How the early believers experienced God, Liturgical Press, Collegeville, MN.

Richeport, M., 1984, 'Macumba, trance and spirit healing', Video, Richeport Films, New York.

Rist, M., 1989, 'millennium', Interpreter's Dictionary of the Bible 3, 381.

Schmithals, W., 1980, Das Evangelium nach Lukas, Theologischer Verlag Zürich, Zürich. (Zürich Bibelkommentare NT 3.1.).

Schutte, P.J.W., 2004, 'Jesus - a kerygma to live by: A postmodern understanding of myth, resurrection and canon', PhD dissertation, Department of New Testament Studies, University of Pretoria.

Scott, B.B., [1989] 1990, Hear then the parable: A commentary on the parables of Jesus, Fortress, Minneapolis, MN.

Segal, R.A., 1989, Religion and the social sciences: Essays on the Confrontation, Scholars Press, Atlanta, GA.

Smith, D.E., 2003, From symposium to Eucharist: The banquet in the early Christian world, Fortress, Minneapolis, MN.

Smith, D.E. \& Taussig, H.E., 1990, Many tables: The Eucharist in the New Testament and liturgy today, SCM, London.

Stevenson, K.W., 1989, The first rites: Worship in the early church, Liturgical Press, Collegeville, MN.

Tart, C.T., [1980] 1982, 'A systems approach to altered states of consciousness', in J.M. Davidson \& R.J. Davidson (eds.), The psychobiology of consciousness, pp. 243-269, Plenum, New York.

Tart, C.T., 2000, 'Investigating altered states of consciousness in their own terms: Statespecific sciences', in M. Velmans (ed.), Investigating phenomenal consciousness: New methodologies and maps, pp. 255-278, Benjamins, Amsterdam.

Theißen, G., 1999, A Theory of primitive Christian religion, transl. J. Bowden, SCM, London.

Theißen, G. \& Merz, A., 1996, Der historische Jesus: Ein Lehrbuch, Vandenhoeck \& Ruprecht, Göttingen.

Thurian, M. \& Wainwright, G., 1983, Baptism and Eucharist: Ecumenical convergence in celebration, Eerdmans, Grand Rapids, MI.

Turner, V., 1987, 'Rites of passage: A few definitions', EncRel(E) 12, 380-386.

Van Aarde, A.G., 1994a, God with us: The dominant perspective in Matthew's story and other essays, HTS suppl. 5, Gutenberg, Pretoria.

Van Aarde, A.G., 1994b, Kultuurhistoriese agtergrond van die Nuwe Testament: Die eerste-eeuse Mediterreense sosiale konteks, Kital, Pretoria.

Van Aarde, A.G., 1995, 'Kerk en teologie op pad na die nuwe millennium: Gedagtes oor die kontekstualisering van die dialektiese teologie in 'n plurale samelewing', HTS Teologiese Studies/Theological Studies 51(1), 39-64.

Van Aarde, A.G., 2000, 'Millennialism, eschatology, and apocalypticism', pape presented at Graduation Ceremony, Hervormde Teologiese Opleiding, Pretoria, n.d.

Van Bruggen, J., 1994, Matteüs: Het evangelie voor Israël, 2 de uitg., Kok, Kampen.

Van Henten, J.W. \& Mellink, O. (reds.), 1998, Visioenen aangaande het einde: Apocaliptische geschriften en bewegingen door de eeuwen heen, Meinema, Zoetermeer.

Van Huyssteen, J.W.V., 1988, 'Paradigms and progress: Inference to the best explanation', in J. Mouton, A.G. van Aarde \& W.S. Vorster (eds.), Paradigms and progress in theology, pp. 81-90, HSRC, Pretoria.

Van lersel, B.M.F., 1964/65, Die wunderbare Speisung und das Abendmahl in de synoptischen Tradition (Mk vi:35-44, viii 1-20 par.)', New Testament 7, 167-194. doi:10.2307/1560311

Van Staden, P., 1991, Compassion - The essence of life: A social-scientific study of the religious symbolic universe reflected in the ideology/theology of Luke, HTS suppl. 4, University of Pretoria, Pretoria.

Zinberg, N.E., 1977, 'The study of consciousness states: Problems and progress', in N.E. Zinberg (ed.), Alternate states of consciousness, pp. 1-36, Free Press, New York. 